\title{
Proposing an organizational framework for the Sharīah Secretariat of Islamic banks in Bangladesh
}

\author{
Md. Kausar Alam
}

BRAC Business School, BRAC University, Dhaka, Bangladesh and

Research Methodology Tools and Systems (rm2s), Dhaka, Bangladesh

Abu Umar Faruq Ahmad

Adjunct Professor of Islamic Economics and Finance, Guidance College, Houston, Texas, USA

Aishath Muneeza

International Centre for Education in Islamic Finance (INCEIF),

Kuala Lumpur, Malaysia

Mosab I. Tabash

College of Business, Al Ain University, Al Ain, United Arab Emirates, and

Md Adnan Rahman

College of Business Administration,

International University of Business Agriculture and Technology, Dhaka, Bangladesh

\begin{abstract}
Purpose - Sharíah Secretariat plays a significant role in assisting Sharíah Supervisory Boards (SSBs) in their role in achieving Shariah compliance in Islamic banks (IBs). The key objective of the study is to develop a organizational framework of the Sharíah Secretariat for the IBs in Bangladesh.

Design/methodology/approach - The study applied qualitative case study research. The data have been collected from 17 respondents through semi-structured interviews from IBs and professional experts in Bangladesh. Findings - This study proposes a full-time Shariah Secretariat and several departments for further enhancement of the Sharíah functions in IBs in Bangladesh. The framework proposed in this study covers the formation, functions, composition, qualification, reporting line, independence, remuneration and terms of appointment of the Shariah Secretariat to set a uniform benchmark for all IBs in Bangladesh. It is anticipated that the outcomes of this research will assist to further strengthen the Sharîah governance of IBs in Bangladesh.

Research limitations/implications - This research contributed to the national and global regulatory authorities and IBs by proposing a Sharíah Secretariat framework for the smooth functioning of the IBs in Bangladesh. The framework proposed in this study covers the formation, functions, composition, qualification, reporting line, independence, remuneration and terms of appointment of Sharı ah Secretariat.
\end{abstract}

(C) Md. Kausar Alam, Abu Umar Faruq Ahmad, Aishath Muneeza, Mosab I. Tabash and Md Adnan Rahman. Published in ISRA International Journal of Islamic Finance. Published by Emerald Publishing Limited. This article is published under the Creative Commons Attribution (CC BY 4.0) licence. Anyone may reproduce, distribute, translate and create derivative works of this article (for both commercial and non-commercial purposes), subject to full attribution to the original publication and authors. The full terms of this licence may be seen at http://creativecommons.org/licences/by/4.0/legalcode.

The authors would like to thank the editor and anonymous reviewers for their valuable time, constructive comments and suggestions for the improvement of the manuscript. The study did not receive any specific fund or research grant. The first author acknowledges the prior published papers from his thesis/research project. The authors used figures from the first author's thesis methodology paper for this study as this research conducted a partial interview protocol out of the main interview protocol.
Framework for the Sharíah Secretariat

Received 1 March 2021

Revised 8 May 2021 8 August 2021

4 November 2021

17 December 2021

Accepted 21 December 2021 
IJIF

14,1

Originality/value - This study proposed a framework which is considered the first organizational framework so far for the Shariah Secretariat of IBs in Bangladesh. IBs can apply this proposed framework to form their Sharíah Secretariat structure.

Keywords Bangladesh, Islamic banks, Shariah governance, Sharıah Secretariat

Paper type Viewpoint

\section{8}

\section{Introduction}

Shariah governance (SG) is the complete system by which Islamic banks (IBs) and Islamic financial institutions (IFIs) ensure Sharíah (Islamic law) principles in business activities and transactions (Ginena and Hamid, 2015). Islamic Financial Services Board (IFSB) (2009) defines the SG system as a process of ensuring Shari'ah compliance in the overall functions and activities of an IFI.

The key aim of SG is to enhance the application of Shariah rules by IFIs. The adoption of such rules confirms the proper functioning of SG, ensures Shariah compliance and protects the interests of depositors, customers, shareholders, as well as all relevant stakeholders of the IFI (Alam et al., 2019). Therefore, it is imperative to have a sound Shariah governance framework (SGF) for IFIs. Institutional Shari'ah Supervisory Boards (SSBs), the Shariah Secretariat (SS) as well as Sharíah officers perform their functions based on the SG guidelines provided by the central bank and developed by individual IBs. The Accounting and Auditing Organization for Islamic Financial Institutions (AAOIFI) and the IFSB are the two foremost organizations that have voluntarily promulgated Shariah guidelines and standards. These guidelines and standards are applied by many countries and IFIs. AAOIFI emphasizes the institutional-level SG guideline, while the IFSB focuses on the regulatory aspects or central banks' guidelines (Hasan, 2011).

Along with the roles and functions of SSBs, the roles of Shari ${ }^{-1}$ ah officers are significant in the SGF. Shariah officers assist SSB members to perform their functions. Shariah officers conduct the initial Sharíah review and perform Sharíah audit functions. Later, the findings are submitted to the SSB for their consideration and approval, which denotes the significance of their works. In addition, the SSB members provide their opinions and Shari ah resolutions based on the report of Shariah officers (IFSB, 2009; BNM, 2019). If the Shariah officers are unable to perform their roles independently and effectively, it will impact on the quality of Shariah compliance. Therefore, there is a need to have a comprehensive organizational framework for the SS of IBs.

In Bangladesh, full-fledged IBs, Islamic banking branches and windows have SSBs to monitor Shariah matters. In addition to the SSB, these institutions have Shariah officers under the Shariah departments who help them produce, maintain and report Shariah documents, as deemed necessary (Abdullah and Rahman, 2017). Currently, full-fledged IBs do not form an SS in their organizational structure to assist their respective SSBs. Thus, it is not possible for the SSBs of full-fledged IBs in Bangladesh to perform their duties effectively as their status is non-executive members who are unable to fully commit to shoulder all Shariah compliance responsibilities. Likewise, even the Shariah officers appointed by these banks are unable to perform the functions of the SS as they have an independent obligation to act as Sharíah compliance officers. As such, a number of researchers have suggested that the functions of SG within IBs should be enhanced by setting up Sharíah departments headed by SS with various Shariah functions (Abdullah and Rahman, 2017; Hassan et al., 2017; Alam et al., 2019, 2020a).

To bridge the existing gap in the SGF applicable to IBs in Bangladesh, it is imperative to develop a comprehensive SS framework. This research intends to fill in this practical gap by proposing a framework that will provide the guidelines and criteria for the proper functioning of an SS. 
This paper is divided into five sections. Followed by this introduction, the second section provides the literature review related to SG in Bangladesh. The third section illustrates the overall data collection procedure. The fourth section outlines the findings of the discussion. The final section draws the conclusion of the research.
Framework for the Sharíah Secretariat

\section{Literature review}

Though the SSB is the primary organ of an IFI that is responsible for achieving Shariah compliance, the role of the SS that assists them in this process is often not given the required importance. Given this lack of recognition, limited research has been carried out on the role of the SS in IFIs. This section, therefore, reviews the literature by exploring the important aspects of the SS in assisting SSBs and IFIs in achieving Shari'ah compliance by highlighting the reasons for the establishment of the SS and its functions in IFIs. It is also pertinent that there is not adequate literature that has specifically dealt with the challenges faced in the establishment of the SS. As such, there is a research gap in this area that needs to be filled.

\section{Reasons for the establishment of the Shari ah Secretariat}

The raison d'être for the establishment of the SS in an IFI is to assist the SSB in its functions. Since SSB members are not full-time employees of an IB or IFI, there is a need to have competent Shariah professionals at the level of IBs and IFIs as well. In this regard, Aziz and Faizal (2012) observe that since the SSB members do not work like regular executives, the SS and its members should have practical knowledge in ușul al-fiqh and fiqh al-mu'ámalāt in order to monitor Shariah issues.

The SS is also established at the regulatory authority's level to assist the apex Sharíah Advisory Council (SAC). For instance, Bank Negara Malaysia (BNM) has established an SS to assist the SAC at the level of the central bank (SAC, n.d.). No literature has provided the precise historical context of the reason for the establishment of the SS. However, what is apparent is that since the formation of SSBs within IFIs, administrative staff have been allocated to ensure the smooth running of the functions of the SAC and the enactment of SGFs. The term "Sharíah Secretariat" has been coined to indicate that having ordinary administrative staff to assist SSBs is not sufficient for SSBs to effectively carry out their functions. As such, the function and organ of SS became an important part of the SGF enacted in different parts of the world, especially to carry out the Shariah research function. In this regard, SGF 2010 issued by BNM is the first SGF in which the SS is given much importance (BNM, 2010, paragraphs 7.25 and 7.26). Paragraph 7.25 of SGF 2010 requires IFIs in Malaysia to establish a Secretariat to serve the Shariah Committee (SC). SGF 2010 was replaced by the Sharíah Governance Policy Document (SGPD) which became effective on April 1, 2020, except for paragraph 12.5. Under part C of the SGPD on the SC, one paragraph is dedicated to the SS (BNM, 2019, paragraph 14). Paragraph 14.1 of the SGPD clearly states that IFIs must have an SS established to serve the SC.

\section{Functions of the Shariah Secretariat}

The functions of the SS are found in some countries like Malaysia for both the apex SAC at the regulatory authority's level and at the in-house SSB's level. For instance, the SS of the SAC of BNM is formed under Section 54 of Central Bank of Malaysia Act 2009, and it is mainly responsible for assisting the SAC in carrying out its functions. Unlike other parts of the world, in Malaysia, the SAC is a statutory body established under Central Bank of Malaysia Act 2009. SAC (n.d.) states that the functions of the SS of the SAC are to assist the SAC in coordinating meetings and operations, delivering Shariah perceptions and opinions and performing research on matters related to Shari ${ }^{-}$ah and assigned issues by the SAC. 
IJIF

14,1

As for the role and functions of an in-house SS in supporting SCs, the SGF 2010 of BNM states that the role of the SS includes inter alia performing managerial functions, liaising meetings, assisting SSB members, conducting research and providing support to stakeholders (BNM, 2010).

The new SGPD of BNM (2019) highlights more details on the roles and responsibilities of the SS than SGF 2010. The new SGPD also includes the qualifications of officers performing the function of the SS. For instance, paragraph 14.1 states that the SS shall provide administrative and managerial support to the SSB and management, conduct research, provide regular suggestions on Shariah matters and circulate the decisions of the SSB within the institution. Paragraph 14.2 of the said policy document further states that IFIs should confirm the Shariah qualities and qualifications of SS officers.

In Pakistan, the SGF for IBs and IFIs issued by the State Bank of Pakistan (2018) requires the SS to be a function of the Sharíah Compliance Department (SCD). Paragraph 5(i) of the said framework states that the SDC shall support SSB members in accomplishing their functions, circulating their decisions and maintaining the official documents and meeting minutes.

The Governance Standard for Islamic Financial Institutions No. 9 of AAOIFI (2020) also has specific sections on the SS. Paragraph 52 of the said standard states that management should support the SS with an adequate number of qualified Shariah officers in the formation and accommodation of its functions. It states, "For any reason, if there are some resource constraints, the SCD can perform the function of the Secretariat of the SSB by following its terms and conditions." Paragraph 53 states that the SS of the SSB shall be headed by the secretary of the SSB, and in case the SCD accomplishes the functions of the SS, the SCD may perform further roles of the SS for the SSB. In this regard, all the functions of the SS will be considered part of the functions of the SCD. Paragraph 54 stipulates the functions and responsibilities of the SS. They are defined as serving the SSB on all matters concerning logistics, documentation and circulation of fatwas, assisting the SSB in the review and issuance of its annual Sharíah report, and preparing the "Actions Taken Reports" to ensure Shariah compliance. Paragraph 55 states that the SS of the SSB can be recruited by the management of the IFI in accordance with suggestions of the SSB.

\section{Methodology}

In order to attain the research objectives, qualitative research is employed involving both secondary and primary data. Secondary data have been collected using books and journal articles to understand the existing practice in the utilization of the SS to assist SSBs in their functions. Secondary data also comprise Shariah standards and framework published by the different standard-setting bodies and regulatory authorities of different countries. To understand the industry practice on the involvement of the SS in assisting SSBs in Bangladesh, primary data were also collected by conducting semi-structured interviews with industry stakeholders and professionals.

This research followed the methodology adopted by Alam et al. (2020a, b, c, d). In their research, they investigated the causes for the absence of a comprehensive SGF for IBs in Bangladesh (Alam et al., 2020b), the formation of a central Shariah regulatory authority (Alam et al., 2020c), the influence of board of directors (BoDs) and management on SG guidelines of IBs in Bangladesh, and problems of SGF of IBs in Bangladesh (Alam et al., 2020d). They found that the main reasons for the absence of a comprehensive SGF for IBs in Bangladesh are the intentions of regulators and concerned stakeholders and the lack of qualified Shariah scholars (Alam et al., 2020a) although the prior research suggested the formation of a central Shariah regulatory authority for IBs in Bangladesh (Abdullah and Rahman, 2017; Hassan et al., 2017; Alam et al., 2019, 2020b, c; Alam, 2020). Along with this, it is 
a requisite that $\mathrm{BB}$ or a third party conduct an external Sharíah review and audit to provide greater assurance on the aspect of Shari'ah compliance (Alam et al., 2020e).

Semi-structured interviews were conducted over the period 23 December 2018 to 20 January 2019 with different clusters of respondents. The study applied semi-structured interviews as this method is more flexible in data collection (Dane, 1990). This interview technique allows the respondents to share their opinions from their practical knowledge and experiences (Saunders et al., 2007). In addition, it is more appropriate to explore more detailed information about the study topic based on the questions set (Berg and Lune, 2007). The semistructured interview method is also useful to explore and understand the research matter, design and processes of behavior, and obtain the respondents' authentic perceptions (Bryman and Bell, 2003).

Therefore, a probable respondent list was developed for data collection, comprising SSB members, Sharíah executives and experts from IBs in Bangladesh. The respondents have practical knowledge concerning the SG functions and activities of the Shariah departments of IBs in Bangladesh. The respondents were provided a formal consent letter to participate in the interviews. Finally, the study undertook 17 interviews to achieve its objectives. The interviews were recorded on a mobile device, and the duration of each interview was 45$60 \mathrm{~min}$. The respondents were assured that their identity would not be disclosed in the research publications and online. All interviews were transcribed word-by-word and doublechecked. The respondents' names were recorded symbolically under different categories. For example, the study uses "SP" for Shari'ah practitioners, "RA" for regulatory authorities and " $\mathrm{E}$ " for experts. Detailed information of the respondents is given in Table 1.

The following key research question was the focus of the interview sessions: How should the SS department be operationalized? In particular, the following sub-questions were addressed to the respondents:

(1) What should be an ideal structure for the SS of IBs in Bangladesh?

(2) How many departments should be in an organizational framework for the SS?

(3) How do you describe the role, power and functions of the SS and Shariah executives in the effective monitoring and functioning of an organizational framework for the SS of IBs in Bangladesh?

(4) What are your views on the independence, effectiveness and qualification requirements of the SS and Sharíah executives?

(5) What is your opinion regarding the standard criteria and procedures for the formation, appointment, remuneration and reporting systems of the SS and Sharíah executives?

To analyze the large textual data which have been collected during the interviews, NVivo software was used as a qualitative and mixed-methods research tool to create codes, categories and themes (Gibbs, 2002; Patton, 2002). NVivo is an effective software in this field that allows researchers to manage data in an environmentally friendly way as it does not require paper and pencil (Alam, 2020).

\section{Findings and discussions}

Based on the responses, the study outlines an SS framework for the effective functioning of SG in IBs in Bangladesh. The functions of an SS can be classified into numerous categories. It is, therefore, the responsibility of the IBs to provide adequate resources for the proper adoption and functioning of the proposed framework.
Framework for the Shariah Secretariat 


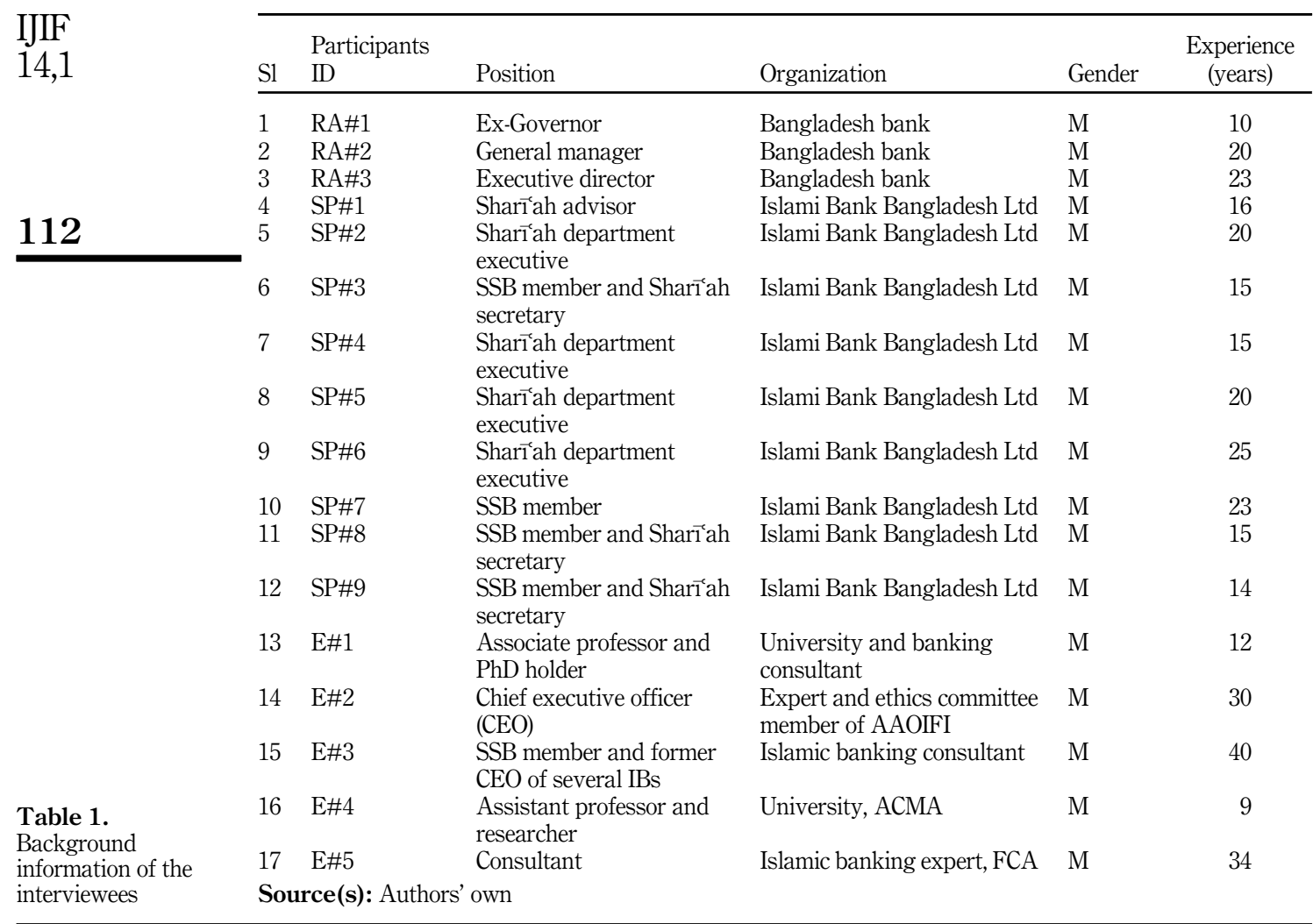

It is observed that the SS and SS officers will play significant roles in applying Sharíah principles within IBs, provided that they have rules and regulations to follow. In this regard, one of the experts (E\#4) states that the functions of Shariah officers in Bangladesh are hampered due to the absence of proper rules and regulations. Therefore, it is expected that a proper SS framework will fill this existing gap and provide guidance in achieving Shariah compliance using a higher standard than what is followed in the industry.

\section{Shariah Secretariat}

With regard to the SS framework, the respondents have provided their opinions on how it ought to be developed, based on their vast experience in the industry. Accordingly, the proposed framework for the SS is provided in Figure 1. The general idea is to create an environment where the SS will be able to work with the management to monitor the Sharíah issues and be responsible for updating information about the Shariah conflicts with the various parties. The SS can be formed with a full-time SSB member and Shariah officers consisting of several Shariah functioning units (State Bank of Pakistan, 2018). The management will be responsible for the overall implementation and monitoring of Sharíah principles in the activities of the IBs. Along with the four major departments mentioned in Figure 1, the respondents suggested the inclusion of additional administrative and customer service departments. 


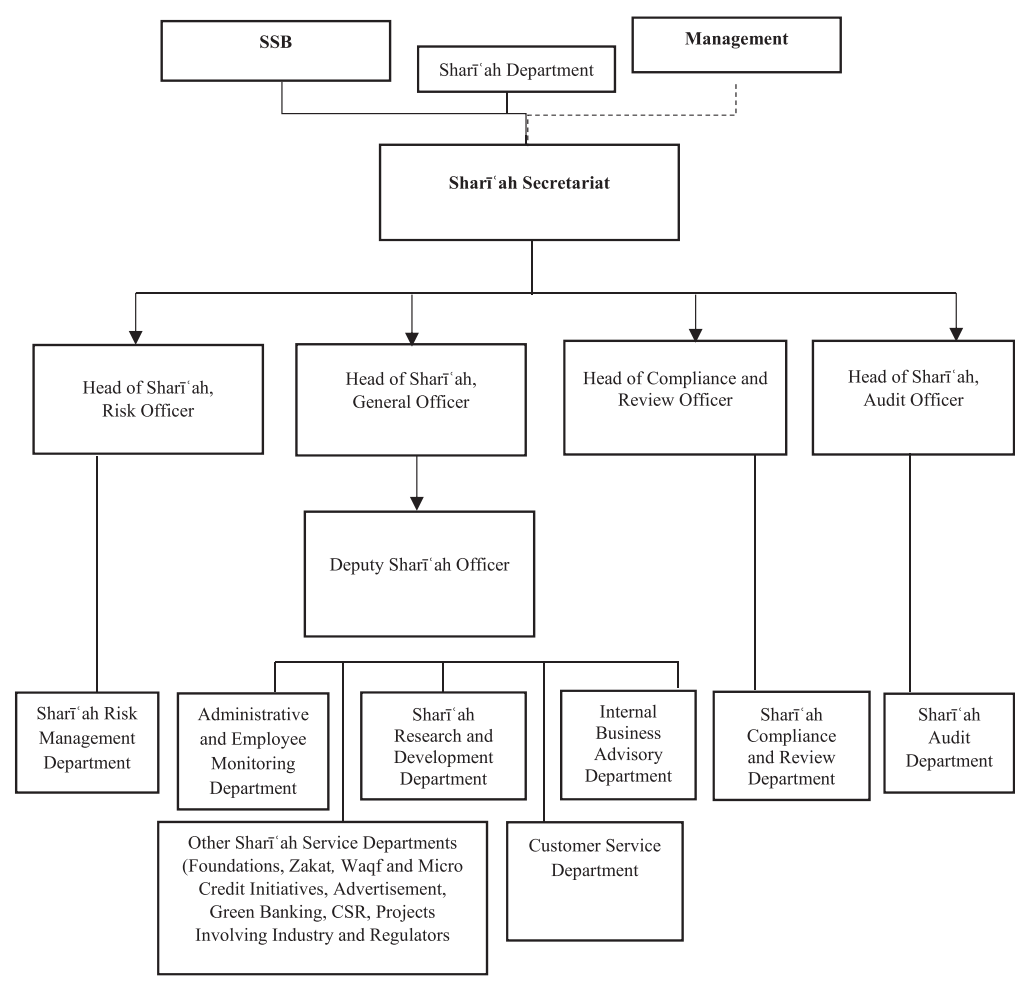

Framework for the Shariah Secretariat

Source(s): Author's own

For proper operation of the SS, the SSB should play its role in the recruitment and promotion of the SS and its officers. SP\#7 suggests that the SS should be formed with a full-time Shariah secretary and executives for accomplishing the Sharíah department functions. If the Shariah officers find any problems in the course of performing their functions, they should report to the Shariah secretary to take immediate actions and solve the problems. They should inform the Shariah secretary and SSB of all matters independently.

Conversely, SP\#3 is of two minds regarding the full-time position of the Shari ah secretary in the SS. On the one hand, he opines that it would be better if the Shariah secretary were a full-time position. On the other hand, he is concerned that if the Shariah secretary is a fulltime executive, there is a possibility that management would influence and create conflict, misunderstanding and bias in the decision-making and functions of the SS. In this regard, if the SSB appoints the Shariah secretary to be in office for a certain period, the SSB might be able to minimize the possible influence or conflict of interest with the SS executives.

\section{Shariah department}

The Shariah department should have a combination of the SS, heads of different departments, Shariah audit officers, compliance officers and general officers. The officers of the respective departments report to the head of those departments, and the heads directly 
IJIF

14,1

report to the Shariah secretary. The Sharicah secretary's reporting system should be made directly to the SSB. There has to be a linkage with the management to ensure the Shariah department functions effectively. SP\#2 believes that this should be done for the independence and benefit of Shariah executives and to establish a better relationship with the management or senior executives. In addition, SP\#2 suggests that the Shariah audit report needs to be presented to the SSB, the audit committee and management, respectively. The respondents agreed with the suggestion that the SS should report to the management indirectly, that they should be accountable to the SSB and that they should provide the report to the board audit committee. Further, if there is any external audit from BB or any other regulatory bodies, they shall also report to them. In this regard, SP\#5 states that it is imperative to have a Shariah audit function under both the audit committee and the SS so as to ensure that a check and balance mechanism with independence is maintained in this function.

Furthermore, respondents E\#3 and SP\#9 recommend that IBs or the concerned authorities should arrange training programs, seminars and discussions to upgrade the executives' knowledge and skills in developing the conventional and Islamic banking functions, Sharíah principles and in addressing other Sharíah issues. Besides, IBs should arrange orientation and motivational programs from time to time for their customers to be motivated and to enhance their knowledge and awareness on Sharíah principles and the functions of banks. Additionally, E\#5 observed that the executives and customers need to accept Shari ah principles from their sides, which will enhance the implementation of Shari ${ }^{\top}$ ah and Shariah compliance quality.

However, the IBs, BoD and top management should also consider resolving Sharíah issues rather than merely focusing on ways in which profit could be maximized. In addition, the management should recruit more Shariah knowledgeable officers for the Shariah department. Ideally, $100 \%$ of the personnel in this department should meet this criterion, but at a very minimum, at least $50 \%$ should be so qualified.

Based on the findings, the study also outlines an organizational framework for the SS to run the comprehensive functions and ensure Sharíah compliance in the IBs' overall functions. Along with the major functions, the Shariah executives should especially be concerned about micro-finance products and services as Bangladesh is contributing more to global micro-finance and small and medium enterprises.

Based on the respondents' responses, the following discusses the critical aspects of the proposed framework for the SS of IBs in Bangladesh which is illustrated in Figure 1.

Formation: Every IB in Bangladesh shall appoint a full-time independent secretariat to assist the SSB in performing its functions effectively and to perform administrative tasks related to SSB meetings including logistics, paper presentations, preparation of minutes or any other functions to support the efficient management of SSB meetings.

Functions: Based on the findings of the interviews and in line with BNM (2019), this research proposes the following functions of the SS for IBs in Bangladesh:

(1) To assist the SSB in all administrative matters, including coordination of meetings and administration;

(2) To liaise between the SSB and management of the respective IB;

(3) To prepare minutes of SSB meetings and/or any other discussions held by the SSB;

(4) To coordinate with the chairman of the SSB, prepare the agenda of SSB meetings and call for these SSB meetings;

(5) To provide Sharíah inputs and views and conduct research on Sharíah issues referred to the SSB by management for discussion in SSB meetings; 
(6) To prepare Shariah opinions based on the SSB's decisions, and publish them with the consent of the chairman of the SSB;

(7) To ensure that relevant departments of the IBs prepare and present papers for discussion in SSB meetings, and that the SSB provide its Shariah opinions on the issues presented in the papers;

(8) To conduct periodic Sharíah review and share the findings with the SSB;

(9) To keep the Sharíah product manuals updated;

(10) To report Shariah non-compliance matters to the SSB;

(11) To prepare rectification plans for Shariah non-compliance matters and present them to the SSB;

(12) To ensure that any queries from clients that need to be addressed by the SSB are sent through the SS to ensure that the decisions of the SSB are practically implemented within the operations of IBs;

(13) The SS shall also be responsible for providing various parties with up-to-date information about Shariah issues.

Composition: Based on the interview findings, the study proposes that the $\mathrm{BoD}$ shall appoint full-time staff to form part of the SS, depending on the size of the institution, and determine the number of members that should constitute the SS. Depending on the circumstance, the $\mathrm{BoD}$ may also decide to outsource the functions of the SS to a competent Shariah advisory firm, which must appoint designated responsible persons for the respective IBs who will be called the SS responsible persons.

Qualification: In case of appointment of individual members, our research findings argue that the majority of the members appointed on the SS shall be qualified Shariah officers who are well-versed in both English and Arabic. The respective IB may assign staff from other departments of the bank to be in the SS, and this could be done on a rotation basis as well.

In case of appointment of a Sharíah advisory firm, the firm shall appoint SS responsible persons who should have the same qualifications as an individual member appointed to the $\mathrm{SS}$, as mentioned above.

Reporting line: According to the interview findings, the SS shall directly report to the SSB and shall only perform functions assigned by the SSB or by the chairman of the SSB.

Independence: The study argues that the SS shall perform their functions independently and shall always act on behalf of the SSB.

Remuneration and term of appointment: The study proposes that the $\mathrm{BoD}$ of the respective $\mathrm{IB}$ shall remunerate the SS as and when it deems fit, and the term of the appointment shall also be determined by the $\mathrm{BoD}$ of the respective IB.

\section{Conclusion}

This study concludes that there is a need for enacting a framework for the SS of IBs in Bangladesh to standardize their roles across IBs with the common objective of facilitating the $\mathrm{SSB}$ in discharging its functions efficiently to achieve overall Shariah compliance in the operations of IBs. Since SSB members are not full-time staff of IBs, they need support staff who will help in administrative matters of the SSB, conduct Sharíah research for them and ensure that the decisions of the SSB are practically implemented within the IBs' operations.

Based on the respondents' responses and discussions, this study therefore outlines a framework for the SS for the effective functioning of SG in IBs of Bangladesh. The functions can be diversified (e.g. research, review, compliance, audit, internal compliance and 
IJIF

14,1

116

monitoring), but the SSB and IBs need to ensure proper mechanisms, sufficient Sharíah executives and the independence of the officers. The particular IB can restructure the SS based on its available resources, capabilities and capacities to enhance the functions of the IB and ensure Sharíah compliance.

In the proposed framework, the SS will work with the management, monitor the Shariah issues and be liable for providing up-to-date information about the matters which are in conflict with the principles of Shariah. The SS can be formed with a full-time SSB member and Shariah officers from respective departments. The management shall be responsible for the overall execution of Shariah principles in the activities of IBs. As for the reporting, the SS should report directly to the SSB and indirectly to the management. They will also assist the external auditor in accomplishing its functions. In the event the Shari ah secretary or officers detect any problems, they should be reported to the SSB independently for taking immediate actions and solving the problems. The management should recruit more Sharíah officers with extensive expertise in Shariah to form part of the Shariah department. For example, $100 \%$ or at least $50 \%$ of the personnel in that department should have that qualification. It is suggested that the SSB should play its proper role in the recruitment and promotion of the SS and its officers.

The study has numerous contributions to the prevailing literature on SG and IBs, particularly in the context of Bangladesh. This study is the first of its kind so far that proposes an SS framework for IBs in Bangladesh, and as such it provides useful insights to the regulatory authorities, policymakers and IBs relating to the organizational structure of the SS and its functions, and to protect the independence of the Shariah officers. The study can further be beneficial in the following ways:

(1) IBs can apply this proposed framework for broadening their Sharíah departments' functions.

(2) Regulators and IBs can apply this structure to strengthen the functions of the SS.

(3) The BoD and management of IBs should ensure an adequate number of Shariah executives to form part of the SS to ensure its effective functioning.

To conclude, IBs should develop their guidelines for the effective operations of this unit in particular and IBs in general. The framework proposed in this study covers the formation, functions, composition, qualifications, reporting line, independence, remuneration and terms of appointment of the SS.

Nevertheless, this study is limited to the IBs of Bangladesh rather than to the IBs of different jurisdictions. The framework may differ given the individual country's context and practice. This study is solely intended to propose an organizational framework for the SS of IBs in Bangladesh; therefore, it did not illustrate the way specific departments operate in practice. Further research can explore or broaden this framework in the context of other countries. The study does not cover the Islamic banking branches and windows run by conventional banks in Bangladesh. In addition, future research can also explore other Islamic institutions' SS such as services rendered by waqf (Islamic endowment) and zakat (Islamic charity) institutions, Islamic micro-finance, halāl (Islamically permissible) industries, and cooperative institutions in the context of Bangladesh.

\section{References}

AAOIFI (2020), "Governance standard for Islamic financial institutions No. 9 of AAOIFI (Sharīah compliance function)", available at: http://aaoifi.com/gsifi-9-Sharíah-compliance-function/? lang=en (accessed 4 October 2021). 
Abdullah, M.F. and Rahman, A. (2017), "Sharīah governance of Islamic banks in Bangladesh: issues and challenges", Journal of Islamic Economics, Banking and Finance, Vol. 13 No. 3, pp. 82-94.

Alam, M.K. (2020), "A systematic qualitative case study: questions, data collection, NVivo analysis and saturation", Qualitative Research in Organizations and Management, Vol. 8, doi: 10.1108/ QROM-09-2019-1825.

Alam, M.K., Rahman, S.A., Mustafa, H., Shah, S.M. and Hossain, M.S. (2019), "Sharíah governance framework of Islamic banks in Bangladesh: practices, problems and recommendations", Asian Economic and Financial Review, Vol. 9 No. 1, pp. 118-132, doi: 10.18488/journal.aefr.2019.91. 118.132 .

Alam, M.K., Mustafa, H., Uddin, M.S., Islam, M.J., Mohua, M.J. and Hassan, M.F. (2020a), "Problems of Sharíah governance framework and its mechanisms: an empirical investigation of Islamic banks in Bangladesh", Journal of Asian Finance, Economics and Business, Vol. 7 No. 3, pp. 265-276, doi: 10.13106/jafeb.2020.vol7.no3.265.

Alam, M.K., Rahman, S.A., Thakur, O.A., Bashir, M.A. and Hosen, S. (2020b), "The reasons behind the absence of a comprehensive Sharîah governance framework for the Islamic banks in Bangladesh”, International Journal of Economics and Business Administration, Vol. 8 No. 1, pp. 134-145, doi: 10.35808/ijeba/414.

Alam, M.K., Tabash, M.I., Thakur, O.A., Sahabuddin, M., Hosen, S. and Hassan, M.F. (2020c), “A central Sharíah regulatory authority for the Islamic banks in Bangladesh: legalization or formation”, Journal of Asian Finance, Economics and Business, Vol. 7 No. 1, pp. 91-100.

Alam, M.K., Miah, M.S., Siddiquii, N. and Hossain, M.I. (2020d), "The influences of board of directors and management in Shariah governance guidelines of the Islamic banks in Bangladesh", Journal of Islamic Accounting and Business Research, Vol. 11 No. 9, pp. 1633-1647, doi: 10.1108/ JIABR-08-2019-0155.

Alam, M.K., Ahmad, A.U.F. and Muneeza, A. (2020e), "External Sharı'ah audit and review committee vis-à-vis Sharı̉ah compliance quality and accountability: a case of Islamic banks in Bangladesh", Journal of Public Affairs, doi: 10.1002/pa.2364.

Aziz, A. and Faizal, A. (2012), "Sharīah governance: challenges ahead", available at: https://mpra.ub. uni-muenchen.de/47772/1/MPRA_paper_47772.pdf (accessed 4 October 2021).

Berg, B.L. and Lune, H. (2007), Qualitative Research Methods for the Social Sciences, Pearson Education, Boston.

BNM (2010), Shari ah Governance Framework 2010, Bank Negara Malaysia, Kuala Lumpur, available at: https:/law.resource.org/pub/my/ibr/ms.bnm.Sharīah.02.2010.pdf (accessed 4 October 2021).

BNM (2019), Shari ah Governance Policy Document, Bank Negara Malaysia, Kuala Lumpur, available at: https://www.bnm.gov.my/index.php?ch $=57$ andpg $=140 \mathrm{andac}=835 \mathrm{andbb}=$ file (accessed 4 October 2021).

Bryman, A. and Bell, E. (2003), Business Research Methods, Oxford University Press, New York.

Dane, F.C. (1990), Research Methods, Brooks/Cole Publishing, Belmont, CA.

Gibbs, G. (2002), Qualitative Data Analysis: Explorations with Nvivo, Open University, Buckingham.

Ginena, K. and Hamid, A. (2015), Foundations of Shari ah Governance of Islamic Banks, John Wiley \& Sons, Chichester, West Sussex.

Hasan, Z. (2011), "Sharīah governance in Islamic financial institutions in Malaysia, GCC countries and the UK", Doctoral Dissertation, Durham University.

Hassan, M.K., Ullah, M.H. and Khanam, R. (2017), "Sharîah governance practices in Bangladesh", in Ali, N. (Ed.), Shari ah Governance Systems and Practices in a Globalized World, available at: http://research.usc.edu.au/vital/access/manager/Repository/usc:25050 (accessed 4 October 2021).

IFSB (2009), Guiding Principles on Shar̃ah Governance Systems for Institutions Offering Islamic Financial Services, Islamic Financial Services Board, Kuala Lumpur.
Framework for the Shariah Secretariat 
IJIF

14,1

Patton, M.Q. (2002), Qualitative Research and Evaluation Methods, 3rd ed., Sage Publications, CA.

Sharīah Advisory Council (SAC) (n.d.), "SAC secretariat", available at: https://www.sacbnm.org/? page_id $=3303$ (accessed 4 October 2021).

Saunders, M., Lewis, P. and Thornhill, A. (2007), Research Methods for Business Students, PrenticeHall, Hemel Hempstead.

State Bank of Pakistan (2018), "Sharīah governance framework for Islamic banking institutions", available at: http://www.sbp.org.pk/ibd/2018/C1-Annex-A.pdf (accessed 4 October 2021).

\section{About the authors}

Md. Kausar Alam, $\mathrm{PhD}$, is currently working as an assistant professor at BRAC Business School, BRAC University, Dhaka, Bangladesh. His research interests include Sharı̈ah governance, Islamic finance, accounting, finance, institutional theory and legitimacy.

Abu Umar Faruq Ahmad, PhD, is an adjunct professor of Islamic Finance at Guidance College, USA. He has published over 100 research papers in different quality journals, edited books and refereed conference proceedings.

Aishath Muneeza, $\mathrm{PhD}$, is an associate professor at International Centre for Education in Islamic Finance (INCEIF), Kuala Lumpur, Malaysia. Aishath Muneeza is the corresponding author and can be contacted at: muneeza.aishath@gmail.com

Mosab I. Tabash, PhD, is working as MBA Director at College of Business, Al Ain University, United Arab Emirates. His research areas include Islamic finance, financial performance, corporate governance and monetary policies.

Md Adnan Rahman is a senior lecturer at the College of Business Administration, International University of Business Agriculture and Technology, Dhaka, Bangladesh. He has a distinguished academic background. He is also a $\mathrm{PhD}$ candidate at Putra Business School, Malaysia.

For instructions on how to order reprints of this article, please visit our website:

www.emeraldgrouppublishing.com/licensing/reprints.htm

Or contact us for further details: permissions@emeraldinsight.com 